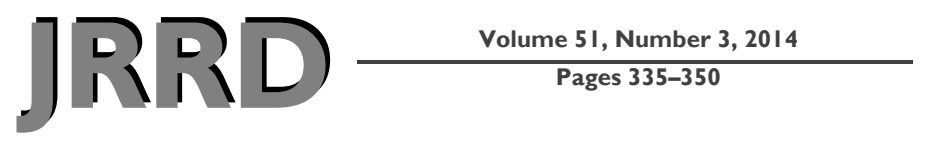

\title{
Systematic review of timed stair tests
}

\author{
Elizabeth Jean Nightingale, PhD; ${ }^{*}$ Fereshteh Pourkazemi, MSc(Physiotherapy); Claire E. Hiller, PhD \\ Faculty of Health Sciences, University of Sydney, Sydney, New South Wales, Australia
}

\begin{abstract}
Functional testing is particularly useful in the clinic and for making research translatable; however, finding measures relevant across ages and different conditions can be difficult. A systematic review was conducted to investigate timed stair tests as an objective measure of functional abilities and musculoskeletal integrity. Data were analyzed for their ability to differentiate between controls and patient groups and between different patient groups. Literature was reviewed using the Medline, CINAHL, and PubMed databases until February 2012. Data were grouped according to methodology, ages, and medical conditions. Time per step was calculated to allow comparison between studies. Eighty-eight studies were included in this review. Methodologies varied considerably with stair ascent, stair descent, or a combination of the two being used across a wide range of ages and medical conditions. Times increased with age for ascent, descent, and combined and for a variety of medical problems. Timed stair tests appear to be sensitive to medical conditions but further data are required to obtain normative values for this test. We suggest that timed stair tests should follow a more standardized methodology using a combination of ascent and descent and asking participants to complete the stairs as quickly and safely as possible.
\end{abstract}

Key words: age groups, functional measure, lower limb, musculoskeletal abnormalities, normative values, reference values, speed, stair navigation, task performance, time.

\section{INTRODUCTION}

Stair negotiation is a commonly performed activity in daily life and useful as a functional measure in a variety of populations [1-5]. However, many current functional assessment scales often neglect stair negotiation completely [6] and the time to complete stairs has largely been neglected as an objective outcome measure. Stair performance has been recognized as important in the Hospital for Special Surgery Score, whereby the ability to perform stair ascent and descent is heavily weighted [7], and the need for more challenging tests other than level walking has been recognized [8], particularly for more able populations.

Biomechanics research in the past has predominantly concentrated on level walking, because this is the gold standard of function and outcome for clinical populations. However, the literature examining stair ascent and descent has made significant gains in the understanding of the kinematics and kinetics of these tasks. Stairs require greater range of motion from the joints of the lower limb and greater muscle strength [9-10], with the demands on the joints and muscles differing between stair ascent and descent [11-12]. Stairs are a more advanced activity of daily living (ADL) and thereby may demonstrate functional difficulties more readily than walking tests.

Stair ascent stresses the cardiorespiratory system to a greater extent than level walking, increasing heart rate and respiratory measures [13]. Stairs therefore also have the benefit of being able to measure multiple systems and highlight the limiting factor(s) between the musculoskeletal,

\footnotetext{
Abbreviations: $\mathrm{ADL}=$ activity of daily living, $\mathrm{SD}=$ standard deviation.

*Address all correspondence to Elizabeth Jean Nightingale, PhD; Physiotherapy, Faculty of Health Sciences, C42, University of Sydney, 75 East St, Lidcombe, NSW, 2141, Australia. Email: jean.nightingale@sydney.edu.au http://dx.doi.org/10.1682/JRRD.2013.06.0148
} 
neurological, and cardiorespiratory systems. This makes one test even more valuable for assessing elderly or frail populations who may have multiple limitations. Information comparing stairs to other commonly used measures [14-15] demonstrates the reliability of measures associated with stairs [15] and their usefulness as an assessment tool directly related to function.

In clinical practice, stairs are increasingly being used as both an assessment tool and as part of exercise programs. Stairs make an excellent functional assessment measure because they are relevant to people's ADLs and have been related to independence and community participation [16-18]. Stairs often arise in measures of functional outcome postsurgery, and a greater understanding of the causes of performance difficulties with stairs can only assist in developing more specific and functional rehabilitation programs.

Of further benefit is the fact that stairs are readily available, convenient, and cheap to use. This article aims to summarize the literature related to timed stair tests. We aimed to determine whether stairs would be able to differentiate between participant groups by age or impairment and whether there were sufficient normative data for comparison as has been done for the timed up-and-go test [19].

\section{METHODS}

\section{Search Strategy}

Relevant articles were identified by searching the PubMed, CINAHL and Medline databases until February 2012. Searches were based on finding the words "stair" and "time" within 10 words of each other, with some other references found by hand searching. Only English references were included for this article.

\section{Eligibility Criteria}

The abstracts of all studies identified by the search strategy were screened by two of the three authors and a consensus was reached. The following criteria were used: (1) in English, (2) had human participants, (3) included data (not a review or protocol), and (4) included a timed measure of stair ascent and/or descent. Later, an additional criterion was added to improve the consistency of the methodology of the studies [20], in that the participants must have been instructed to perform the test as quickly and safely as possible. This command was felt to give a more consistent performance than allowing participants to use a self-selected pace.

\section{Data Extraction and Analysis}

Data were extracted by two of the three authors for all studies. Extraction included the size and type of participant population and treatment received, if a clinical trial. The methodology used was recorded, including the number of stairs used; whether studies assessed ascent, descent, or both; and the manner in which the stairs were performed (e.g., as quickly as possible, at a safe or comfortable pace, with or without use of handrails). The times obtained for all stair tests (mean \pm standard deviation [SD]) were extracted. All stair times were divided by the number of stairs to generate a mean time in seconds per step. Studies reporting ascent and descent separately were not compared with those that examined the combination of stair ascent and descent. In prospective studies only baseline measures were directly compared.

\section{RESULTS}

PubMed, Medline, CINAHL and some reference-list searching generated 650 references after removing duplicates. A further 98 papers were excluded because they were not in English or did not study adult humans (Figure).

Of the remaining 551 references, 38 were not published research papers, 90 did not include a physical stair test, 196 did not include data on the times achieved, and 134 did not ask the participants to complete the stairs as fast or as quickly as possible. On examination of the data from the full text, a further 5 studies were excluded because the baseline data were duplicate data from other papers.

The 88 studies included used a variety of methodology. Ascent, descent, or a combination of both directions of the stairs including the turnaround time were considered. Interestingly, no studies looked at a combined ascent/descent time for the younger population or the medical groups. This variability in methodology has hampered the ability to compare groups, and there are insufficient data for some comparisons as well as groups that do not fit the expected trends.

A wide range of populations were covered in the studies, from the healthy young to the healthy elderly to those with mobility limitations and patient populations. Patient populations included those with musculoskeletal problems (arthritis, joint replacement, or fractures of the lower 


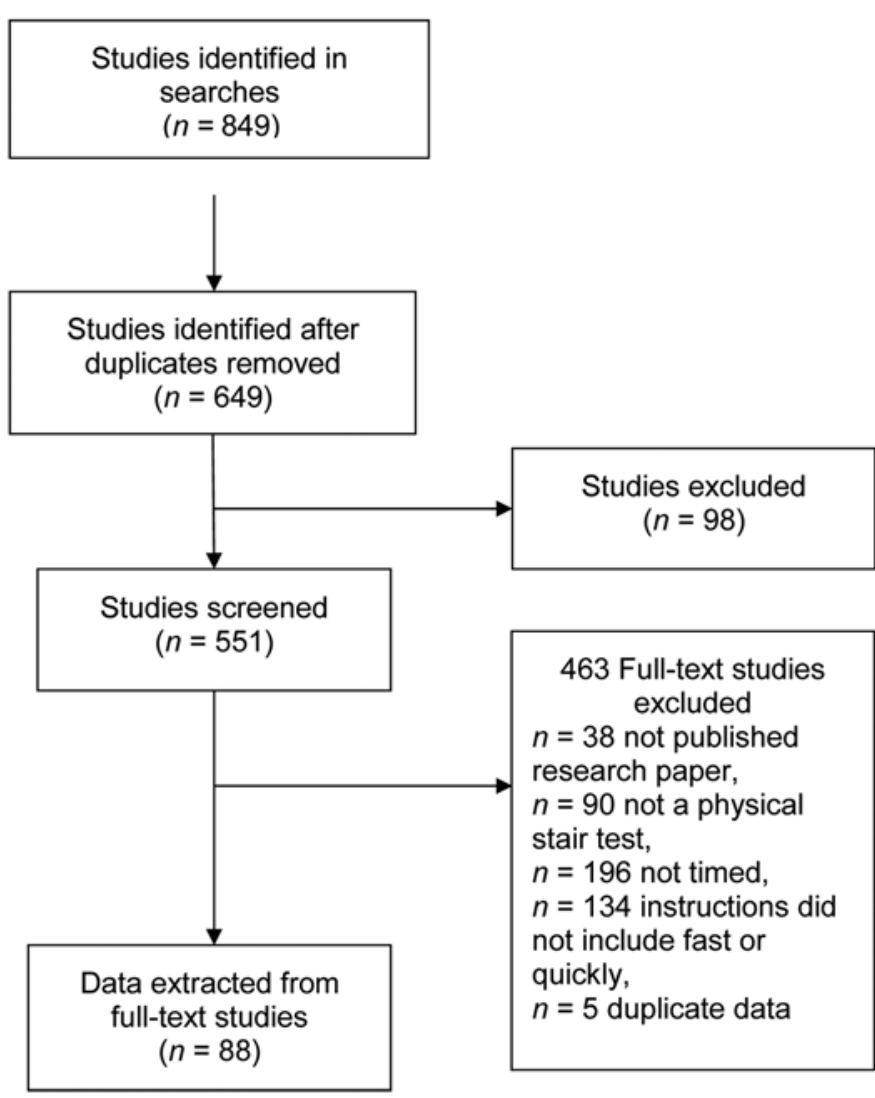

Figure.

Flowchart of search.

limb), medical conditions (cardiac arrhythmias, respiratory conditions, chronic obstructive pulmonary disease, cancer, or long-standing kidney disease), and neurological conditions (stroke, Parkinson disease, multiple sclerosis, Charot-Marie-Tooth, Down syndrome, or cerebral palsy). To examine the quantity of data, the healthy or control group data were separated by age groups (Table 1), because many feel that the ability to use stairs deteriorates with age [21]. The patient data were also grouped by neurological (Table 2), medical (Table 3), and musculoskeletal conditions (Table 4) to see whether different types of limitations would affect the data.

Due to the large number of studies, a summary of the number of studies in an area, number of participants, and time per stair is provided in Table 5. This gives an indication of how thoroughly a group has been investigated and the robustness of the associated data. A good example is comparison of the data for subjects older than 65 with and without mobility restrictions: those with mobility restric- tions appear to descend stairs faster, which does not fit the expected trend. This may well have occurred because of the small number of studies using this methodology and relatively small participant numbers in the groups.

Overall within the healthy population, the expected trends are seen. It takes longer to ascend than descend stairs. The length of time to ascend or descend stairs, or a combination of both, increases with age. Comparing ascent and descent when measured singly to a combined stair ascent and descent time, only the neurological group took longer with a combined ascent and descent methodology than when the ascent and descent time were added together.

Finally, of the 88 studies considered, 54 were treatment or longitudinal studies, using stairs as an outcome measure to evaluate the effect of treatment or changes over time. Forty-eight (89\%) of these studies found a change in the ability to negotiate stairs, with the effects varying between the time and treatment domains depending on the study, suggesting that stairs may be a sensitive measure of functional performance. However, because of the wide variety of treatments and participant groups considered, no further analysis of this has been attempted in this review.

\section{DISCUSSION}

As expected and predicted by the literature, measures of timed stair tests increase with increasing age and demonstrate differences between groups based on impairment. However, due to insufficient data and inconsistencies in methodology, normative values are insufficient for any group, except possibly the over 65 age group.

Timed stair tests are increasingly used in a range of research and clinical situations as an easy-to-administer, objective test of functional ability. However, the lack of normative data hampers the ability to use these data except to measure change over time [22]. Studies are continuing to examine data to differentiate between healthy and injured young people because commonly used objective measures, mainly based around level walking, are not sufficiently challenging for these groups [23]. Objective functional measures also continue to be more discerning than patient self-reports of function [24].

The data obtained in this review do suggest that there are measurable differences between groups and that the method of testing may influence the size of the differences found. However, there are still gaps in the data, 
JRRD, Volume 51, Number 3, 2014

Table 1.

Stair times (in seconds) for healthy participants grouped by age (mean per step of baseline values for each group).

\begin{tabular}{|c|c|c|c|c|c|}
\hline Publication & No. of Participants \& Description & Method & $\begin{array}{l}\text { Ascent } \\
\text { (s) }\end{array}$ & $\begin{array}{l}\text { Descent } \\
\text { (s) }\end{array}$ & $\begin{array}{c}\text { Ascent/Descent } \\
\text { (s) }\end{array}$ \\
\hline \multicolumn{6}{|l|}{$\overline{18-49}$ yr } \\
\hline Butler et al. (2009) [14] & 50 young men (age $28.4 \pm 4.7$ ) & $\begin{array}{l}\text { Ascent \& descent } 8 \text { steps; } \\
\text { median time }\end{array}$ & 0.40 & 0.34 & - \\
\hline Haus et al. (2007) [36] & 20 young persons (age $25 \pm 1$ ) & Ascent 10 steps & 0.26 & - & - \\
\hline LeBrasseur et al. (2008) [37] & 30 young men (age $38.7 \pm 1.4$ ) & Ascent 12 steps & 0.29 & - & - \\
\hline Lindeman et al. (1998) [27] & 20 Con (age $35 \pm 11)$ & $\begin{array}{l}\text { Ascent \& descent of } 10 \text { steps; } \\
\text { median time }\end{array}$ & 0.59 & 0.58 & - \\
\hline Sartorio et al. (2003) [38] & $\begin{array}{l}200 \text { obese subjects in } 3 \mathrm{wk} \text { body mass } \\
\text { reduction program } \\
\text { (age } 49.7 \pm \text { [standard error }] 1.0 \text { ) }\end{array}$ & Ascent 13 steps & 0.36 & - & - \\
\hline Sartorio et al. (2004) [39] & $\begin{array}{l}1273 \text { obese subjects in body mass } \\
\text { reduction program (age } 45.3 \pm 15.4 \text { ) }\end{array}$ & Ascent 13 steps & 0.38 & - & - \\
\hline Sartorio et al. (2001) [40] & $\begin{array}{l}230 \text { obese subjects in body mass } \\
\text { reduction program } \\
(\text { age } 49.9 \pm \text { [standard error }] 0.9)\end{array}$ & Ascent 13 steps & 0.55 & - & - \\
\hline Sartorio et al. (2001) [41] & $\begin{array}{l}60 \text { obese subjects in body mass } \\
\text { reduction program } \\
\text { (age } 39.6 \pm 14.6 \text { ) }\end{array}$ & Ascent 13 steps & 0.34 & - & - \\
\hline Teh \& Aziz (2000) [25] & $\begin{array}{l}103 \text { healthy Con } \\
\text { (age } 44.8 \pm 13.9): n=18 \mathrm{Val}\end{array}$ & Ascent 180 steps & $\begin{array}{l}\text { o } 0.62, \\
\text { o } 0.67, \\
\text { Val o } 0.53 \text {, } \\
+0.56\end{array}$ & - & - \\
\hline Teh \& Aziz (2002) [26] & 103 healthy Con (age $44.1 \pm 13.4$ ) & Ascent \& descent 180 steps & 0.63 & 0.57 & - \\
\hline \multicolumn{6}{|l|}{$50-65$ yr } \\
\hline Eyigor et al. (2008) [42] & 33 Con (age $60.27 \pm 10.70)$ & Ascent/descent 10 steps & - & - & 0.94 \\
\hline Grant et al. (2004) [43] & $\begin{array}{l}26 \text { overweight participants } \\
\text { (age } 63 \pm 4): 13 \text { exercisers, } \\
13 \text { Con }\end{array}$ & Ascent/descent 12 steps & $\begin{array}{l}\mathrm{Rx} 0.58 \\
\text { Con } 0.68\end{array}$ & $\begin{array}{l}\text { Rx } 0.75 \\
\text { Con } 0.91\end{array}$ & $\begin{array}{l}\mathrm{Rx} 1.35 \\
\text { Con } 1.58\end{array}$ \\
\hline Parisi et al. (2006) [44] & 28 Con (age $58.4 \pm 12.4)$ & Ascent \& descent 10 steps & 0.336 & 0.338 & - \\
\hline Petterson et al. (2007) [45] & 44 Con (age $61.3 \pm 7.7)$ & Ascent/descent 12 steps & - & - & $\begin{array}{l}\text { o } 0.68 \\
\text { 이 } 0.83\end{array}$ \\
\hline Yoshida et al. (2008) [46] & $\begin{array}{l}12 \text { Con matched for age } \\
(61.6 \pm 6.2) \& \text { body mass }\end{array}$ & Ascent/descent 12 steps & - & - & 0.72 \\
\hline \multicolumn{6}{|l|}{ Over 65 yr } \\
\hline Butler et al. (2009) [14] & $\begin{array}{l}684 \text { community-dwelling elderly } \\
\text { (age } 80.1 \pm 4.4 \text { ) }\end{array}$ & $\begin{array}{l}\text { Ascent \& descent } 8 \text { steps; } \\
\text { median time }\end{array}$ & 0.63 & 0.63 & - \\
\hline Capodaglio et al. (2007) [47] & 38 healthy elderly (age $77.0 \pm 3.5$ ) & $\begin{array}{l}\text { Ascent/descent } 2 \text { flights of } 12 \\
\text { steps }\end{array}$ & - & - & 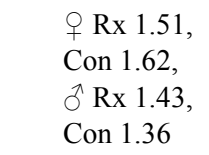 \\
\hline $\begin{array}{l}\text { Christiansen \& Stevens-Lapsley } \\
(2010)[48]\end{array}$ & 17 Con (age $66.8 \pm 6.5)$ & Ascent/descent 12 steps & - & - & 0.74 \\
\hline Eyigor et al. (2007) [49] & 33 healthy adults (age $70.3 \pm 6.5$ ) & Ascent/descent 10 steps & - & - & 1.10 \\
\hline Eyigor et al. (2009) [50] & $\begin{array}{l}37 \text { healthy adult volunteers } \\
\text { (age } 72.0 \pm 6.5 \text { ) }\end{array}$ & Ascent/descent 10 steps & - & - & $\begin{array}{ll}\text { Gp1 } & 1.00 \\
\text { Gp2 } & 1.10\end{array}$ \\
\hline $\begin{array}{l}\text { Farquhar \& Snyder-Mackler } \\
(2010)[51]\end{array}$ & 50 Con (age $66.4 \pm 8.5)$ & Ascent/descent 12 steps & - & - & 0.81 \\
\hline Galvao \& Taaffe (2005) [52] & $\begin{array}{l}28 \text { community-dwelling men and } \\
\text { women (age } 69 \pm 4.6 \text { ) }\end{array}$ & Ascent 11 steps & $\begin{array}{ll}\mathrm{Rx} 1 & 0.48 \\
\mathrm{Rx} 2 & 0.41\end{array}$ & - & - \\
\hline Haus et al. (2007) [36] & 22 older persons (age $78 \pm 1$ ) & Ascent 10 steps & 0.46 & - & - \\
\hline Henwood \& Taaffe (2006) [53] & $\begin{array}{l}67 \text { independent-living older adults } \\
(\text { age } 70.0 \pm 4.5)\end{array}$ & Ascent 11 steps & $\begin{array}{l}\mathrm{Rx} 10.44 \\
\mathrm{Rx} 20.44 \\
\text { Con } 0.45\end{array}$ & - & - \\
\hline Hirota et al. (2010) [54] & 493 active elderly (age 73.5 ) & Ascent/descent 4 steps & - & - & $\begin{array}{l}\text { ô } 1.32 \\
\text { ㅇ } 1.47\end{array}$ \\
\hline LeBrasseur et al. (2008) [37] & 31 older men (age $68.4 \pm 1.4$ ) & Ascent 12 steps & 0.42 & - & - \\
\hline
\end{tabular}


Table 1. (cont)

Stair times (in seconds) for healthy participants grouped by age (mean per step of baseline values for each group).

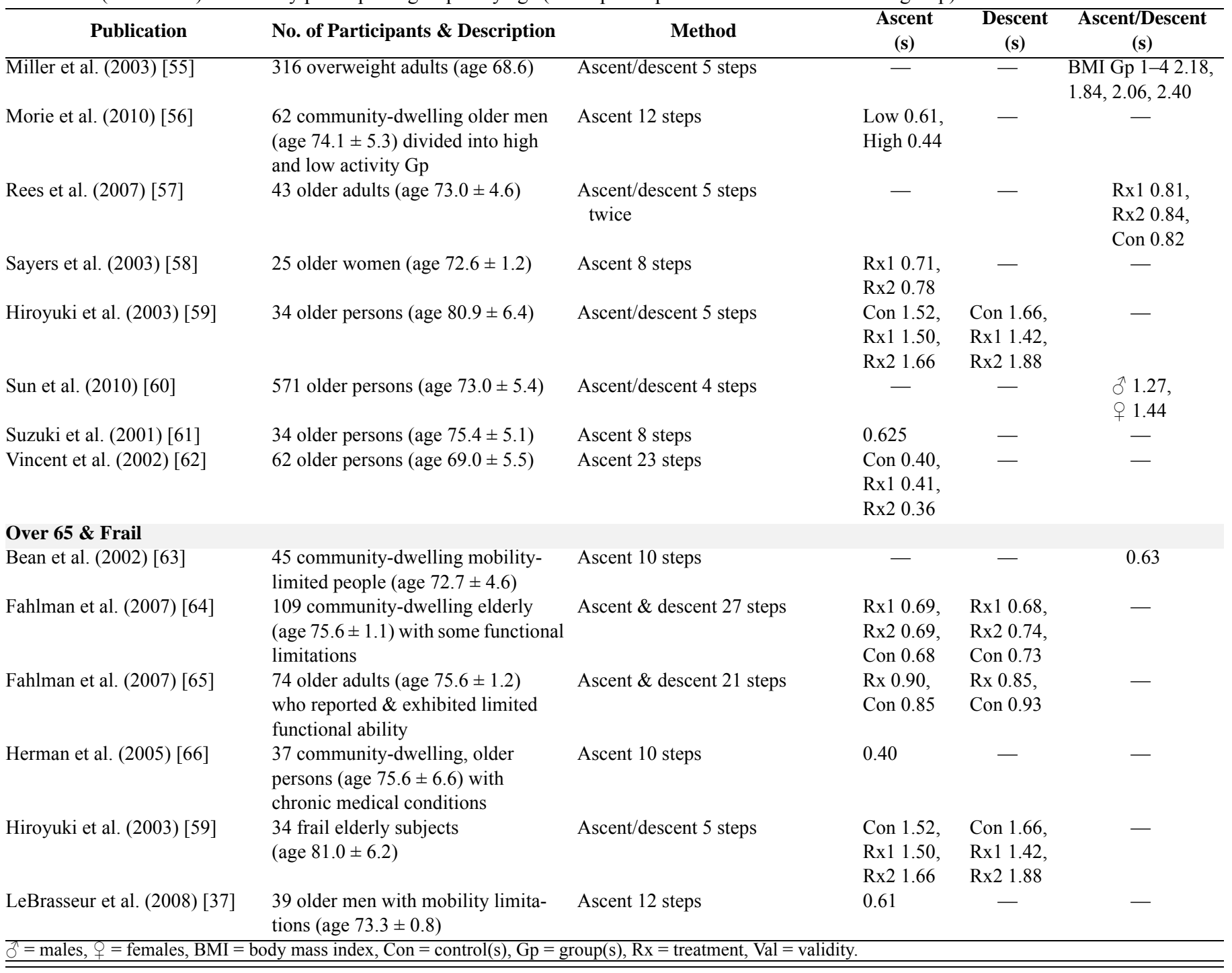

making normative data at present insufficient. Highlighting the insufficiencies is a recently published study by Wilkin et al. [22], which investigated stair ascent in young military personnel. The values are very quick (mean $2.82 \pm 0.37 \mathrm{~s}$ for 12 stairs or $0.23 \mathrm{~s} / \mathrm{step}$ ) in comparison with the results of this review ( $0.49 \mathrm{~s} / \mathrm{step})$ and may reflect the young, active participant group. The data obtained in this review for the young group (18-49 yr), although appearing sufficient to possibly be close to a normative value, were influenced by four of the nine studies being from studies examining participants who were healthy but obese and a further two of the studies [25-26] using a stairway of 180 stairs. Hypotheses would be that the data from this review would be slower than expected for a young healthy population. However, further data collection in homogenous participant groups and with consistent methodology should produce data with smaller SDs to demonstrate more clearly the differences between groups and data for normative values.

In the studies considered, the length of the stairs used varied and appeared to be predominantly influenced by availability. The influence of stair length can be primarily seen in the 18-49 age group (Table 1), where the Teh and Aziz studies have used a significantly longer stairway (180 vs 13 steps) [25-26], with the result being an increase in the time per step for those studies. As well as influencing 
JRRD, Volume 51, Number 3, 2014

Table 2.

Stair times (in seconds) for neurological conditions (mean per step of baseline values for each group).

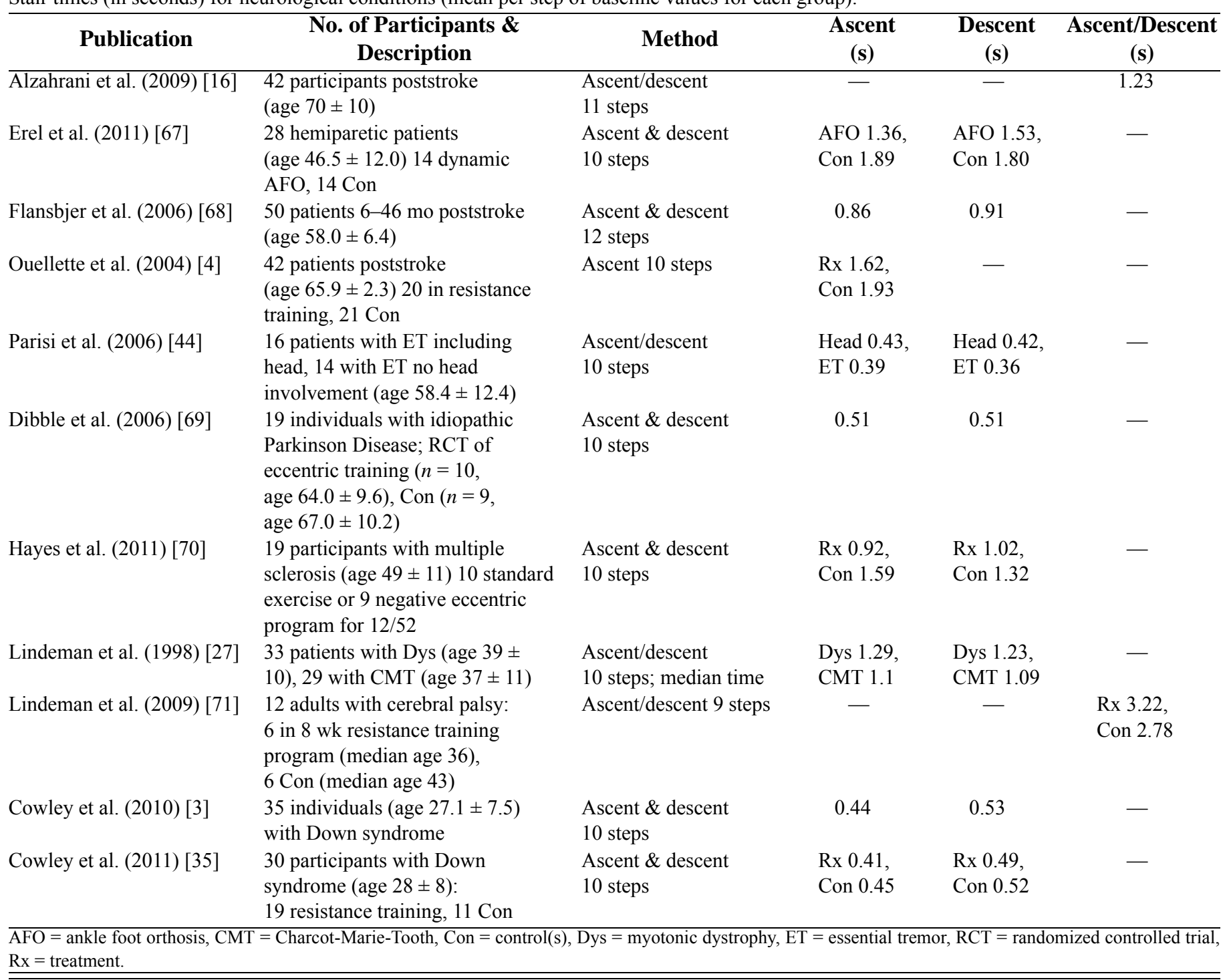

performance times, increased stair length can also influence the limiting factor of performance to the cardiovascular system over musculoskeletal limitations such as muscle strength and joint range.

Another methodological consideration that was taken note of in the first round of data extraction, and that could be important to performance times, was the use of handrails or assistive devices. However, by limiting study inclusion to those asking participants to do the stairs as quickly or fast as possible, the use of handrails became less variable, with all articles instructing participants not to use the handrails or to use them for balance only.
This review suggests that stair ascent time increases with age, with stair descent time increasing to a greater extent. However, analysis is incomplete because of the lack of data in the young healthy group for combined ascent and descent. Considering the three studies that looked at both stair ascent and descent individually in the 18-49 age group [14,26-27], stair descent in these studies was faster than ascent. Given the small number of studies, one could hypothesize that further data collection would confirm this trend and that stair descent would be faster than ascent in 18-49 yr olds. Stair descent may deteriorate to a greater extent with aging, possibly making this a more sensitive measure than stair ascent. Alternatively, 
Table 3.

Stair times (in seconds) for medical conditions (mean per step of baseline values for each group).

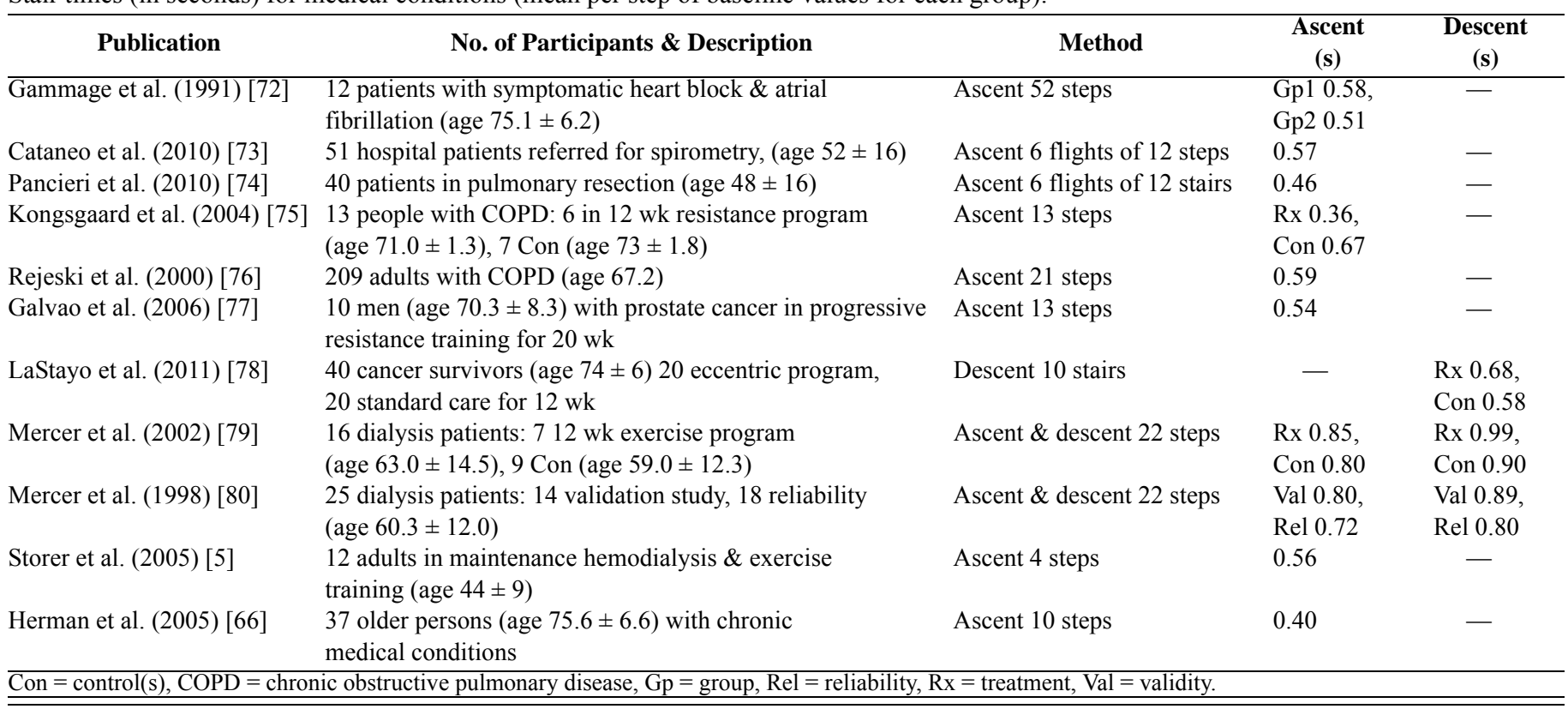

combining stair ascent and descent in the methodology may be sufficient to provide a sensitive measure to differentiate between age groups and patient groups, with the present available data suggesting differences between patient groups and matched controls, e.g., those with neurological and musculoskeletal problems and healthy groups of a similar age.

This review has determined gaps but demonstrates trends similar to those reported by Bohannon [19] in the timed up-and-go test of increasing times with age but overlapping values between age bands. Bohannon used smaller age bands, because of the participant age range being smaller than this study; however, their conclusions were very similar, with a call for a more consistent methodology being required. The overlapping values between the age bands also meant that reference values for belowaverage performance were only determined as those times above the upper limit of the confidence band, possibly due to a lack of homogeneity in the groups; however, the bigger age ranges used in this study also demonstrated overlapping values between age bands.

Timed stair tests appear to have moderate validity as a functional measure, with correlations being present to other functional measures (e.g., timed up-and-go test $[15,23]$, walking speed [14,28-29], sit to stand [14,30], alternate step [14]). Functional tests (e.g., timed up-andgo and sit to stand) all appear to be composite measures of strength and balance [31-33], and stair tests are no different, correlating to balance tests (functional reach test $[15,23]$, timed one-legged stance [15], coordinated stability [14], near tandem balance [14]), and strength [9,28,34-35]. However, these correlations have been investigated most in participant groups, including the elderly and those with disabilities. These correlations need to be considered over the wider population because young and healthy participant data are more likely to be influenced by ceiling effects, which are commonly found in other functional measures. Correlations to both strength and balance and the differences between stair ascent and descent with aging also generate questions about the mechanism of the changes seen with age. Is eccentric strength altered detrimentally first over concentric strength? Or is it the combined challenge of the increased balance requirements with stair descent that slows the completion times?

For stairs to become a comparable measure between sites and projects, the manner in which the test is administered needs to be standardized. We found that testing just ascent or descent or combined ascent/descent did lead to differing results. One would expect those with greater balance issues, such as the elderly and patients with neurological problems, to be particularly slower if a combined ascent/ descent was used, which the data support for the neurological group. However, unequal group sizes in the 
JRRD, Volume 51, Number 3, 2014

Table 4.

Stair times (in seconds) for musculoskeletal conditions (mean per step of baseline values for each group).

\begin{tabular}{|c|c|c|c|c|c|}
\hline Publication & No. of Participants \& Description & Method & $\begin{array}{l}\text { Ascent } \\
\text { (s) }\end{array}$ & $\begin{array}{l}\text { Descent } \\
\text { (s) }\end{array}$ & $\begin{array}{c}\text { Ascent/Descent } \\
\text { (s) }\end{array}$ \\
\hline Galea et al. (2008) [81] & $\begin{array}{l}23 \text { patients (age } 67.6 \pm 8.8 \text { ) with unilateral } \\
\text { THR: } 11 \text { center-based, } 12 \text { home-based } \\
\text { exercise program }\end{array}$ & Ascent 4 steps & $\begin{array}{l}\text { Center } 1.05 \text {, } \\
\text { Home } 0.93\end{array}$ & - & - \\
\hline Pua et al. (2010) [82] & $\begin{array}{l}67 \text { adults with hip OA: } 27 \hat{\delta}, 40 \stackrel{+}{\text { (age } 61 \pm 10)}\end{array}$ & Ascent/ descent 6 steps & - & - & $\begin{array}{l}\text { ㄱ } 1.03 \\
\text { ㅇ } 1.2\end{array}$ \\
\hline Pua et al. (2009) [83] & 100 adults with hip OA (age $62 \pm 10$ ) & Ascent/ descent 6 steps & - & - & 1.15 \\
\hline Lin et al. (2001) [30] & $\begin{array}{l}106 \text { subjects with knee or hip OA } \\
(\text { age } 69.4 \pm 5.9)\end{array}$ & Ascent/ descent 4 steps & 1.04 & 1.02 & - \\
\hline Marsh et al. (2003) [84] & $\begin{array}{l}313 \text { people with knee pain \& difficulties } \\
\text { in ADLs (age } 71.8 \pm 5 \text { ) }\end{array}$ & Ascent/ descent 5 steps & - & - & 1.80 \\
\hline Miller et al. (2006) [85] & $\begin{array}{l}87 \text { obese adults with knee pain (age } 69.5 \pm \\
0.9 \text { ): } 31 \text { weight loss program, } 36 \text { Con for } \\
6 \text { mo }\end{array}$ & Ascent/ descent 5 steps & - & - & $\begin{array}{l}\text { Rx } 1.84 \\
\text { Con } 2.14\end{array}$ \\
\hline Miller et al. (2008) [86] & $\begin{array}{l}67 \text { obese adults with knee pain (age } 69.7 \pm \\
1.0 \text { ): } 31 \text { weight loss program, } 36 \text { Con for } \\
6 \text { mo }\end{array}$ & Ascent/ descent 5 steps & - & - & 1.90 \\
\hline $\begin{array}{l}\text { Christiansen \& Stevens- } \\
\text { Lapsley (2010) [48] }\end{array}$ & $\begin{array}{l}50 \text { participants with knee OA } \\
\text { (age } 64.1 \pm 8.4)\end{array}$ & Ascent/ descent 12 steps & - & - & 1.54 \\
\hline Durmus et al. (2007) [87] & $\begin{array}{l}50 \text { women with knee OA (age } 54.7 \pm 2.0 \text { ): } \\
25 \text { electrical stimulation \& } 25 \text { biofeedback }\end{array}$ & Ascent/ descent 10 steps & - & - & $\begin{array}{ll}\mathrm{Rx} 1 & 2.36 \\
\mathrm{R} x 2 & 2.37\end{array}$ \\
\hline Mizner et al. (2005) [88] & $\begin{array}{l}40 \text { TKR patients (age } 64 \pm 9 \text { ): } \\
\text { presurgery, } 1,2,3, \& 6 \text { mo postsurgery }\end{array}$ & Ascent/ descent 12 steps & - & - & 1.67 \\
\hline Mizner et al. (2005) [89] & $\begin{array}{l}40 \text { TKR patients (age } 63 \pm 8 \text { ) pre- } \& \\
1 \mathrm{yr} \text { postsurgery }\end{array}$ & Ascent/ descent 12 steps & - & - & 1.63 \\
\hline Ni et al. (2010) [90] & $\begin{array}{l}35 \text { older Chinese women (age } 63.2 \pm 2.8) \\
\text { with knee OA; RCT with tai chi }(18 \mathrm{Rx} \text {, } \\
17 \text { Con) }\end{array}$ & Ascent/ descent 5 steps & - & - & $\begin{array}{l}\text { Rx } 1.83 \\
\text { Con } 1.87\end{array}$ \\
\hline Petterson et al. (2007) [45] & 44 patients with knee OA (age $62.3 \pm 6.8$ ) & Ascent/ descent 12 steps & - & - & $\begin{array}{l}\text { o } 1.12 \\
\text { ㅇ } 1.78\end{array}$ \\
\hline Rejeski et al. (1995) [91] & $\begin{array}{l}440 \text { adults with knee OA (age } 68.8 \pm 5.6 \text { ): } \\
\text { aerobic, strength, or education program }\end{array}$ & Ascent/ descent 5 or 9 steps & - & - & $\begin{array}{l}5 \text { steps } 2.04 \\
9 \text { steps } 1.95\end{array}$ \\
\hline Swank et al. (2011) [92] & $\begin{array}{l}71 \text { participants scheduled for TKR } \\
\text { (age } 62.9 \pm 7.5): 35 \text { usual care, } 36 \text { usual } \\
\text { care }+ \text { exercise for } 4-8 \mathrm{wk}\end{array}$ & Ascent \& descent 11 steps & $\begin{array}{l}\text { Rx1 } 1.07, \\
\text { Rx2 } 1.0, \\
\text { Con1 } 0.94, \\
\text { Con2 } 0.98\end{array}$ & $\begin{array}{l}\text { Rx1 1.18, } \\
\text { Rx2 1.04, } \\
\text { Con1 } 0.98, \\
\text { Con2 } 1.10\end{array}$ & - \\
\hline Talbot et al. (2003) [93] & $\begin{array}{l}34 \text { older persons with knee OA } \\
\text { (age } 70.2 \pm 5.7): 17 \text { pedometer } \mathrm{Gp} \text {, } \\
17 \text { education }\end{array}$ & Ascent/ descent 4 steps & - & - & $\begin{array}{l}\operatorname{Rx} 12.54 \\
\text { Con } 1.80\end{array}$ \\
\hline Talbot et al. (2003) [94] & $\begin{array}{l}30 \text { older persons with knee OA } \\
\text { (age } 70.5 \pm 5.3 \text { ): } 18 \text { electrical } \\
\text { stimulation } 12 \text { wk program, } 16 \text { Con }\end{array}$ & Ascent/ descent 4 steps & - & - & $\begin{array}{l}\mathrm{Rx} 2.04 \\
\text { Con } 1.79\end{array}$ \\
\hline Topp et al. (2002) [95] & $\begin{array}{l}102 \text { knee OA adults (age } 63.3 \text { ): } 35 \text { Con, } \\
35 \text { dynamic, } 32 \text { isometric exercise }\end{array}$ & Ascent \& descent 23 steps & $\begin{array}{l}\text { Con } 0.82 \\
\operatorname{Rx} 10.82 \\
\operatorname{Rx} 20.78\end{array}$ & $\begin{array}{l}\text { Con } 0.78 \\
\operatorname{Rx} 0.84 \\
\operatorname{Rx} 20.73\end{array}$ & - \\
\hline $\begin{array}{l}\text { Farquhar \& Snyder- } \\
\text { Mackler (2010) [51] }\end{array}$ & $\begin{array}{l}\text { Post-TKA (age } 66.4 \pm 8.5 \text { ): } 183 \text { at } 1 \mathrm{yr} \text {, } \\
124 \text { at } 2 \mathrm{yr}, 52 \text { at } 3 \mathrm{yr}\end{array}$ & Ascent/ descent 12 steps & - & - & $\begin{array}{l}1 \text { yr } 1.04 \\
2 \text { yr } 1.05 \\
3 \text { yr } 1.05\end{array}$ \\
\hline Gur \& Cakin (2003) [96] & $\begin{array}{l}18 \text { women with bilateral knee OA } \\
\text { (age } 56+10 \mathrm{yr} \text { ) }\end{array}$ & Ascent/ descent 12 steps & 0.59 & 0.62 & - \\
\hline Jan et al. (2008) [97] & $\begin{array}{l}43 \text { subjects with knee OA (age } 63.3 \pm 8.1 \text { ): } \\
20 \text { exercise, } 23 \text { Con }\end{array}$ & Ascent/ descent 13 steps & - & - & $\begin{array}{l}\mathrm{Rx} 2.63 \\
\text { Con } 2.48\end{array}$ \\
\hline Kraemer et al. (2004) [98] & $\begin{array}{l}40 \text { people with knee OA (age } 63.7 \pm 11.1 \text { ): } \\
20 \text { topical CFA cream, } 20 \text { placebo }\end{array}$ & Ascent/ descent 11 steps & - & - & $\begin{array}{l}\mathrm{Rx} 1.25 \\
\text { Con } 1.15\end{array}$ \\
\hline Maly et al. (2005) [99] & $\begin{array}{l}54 \text { patients with medial compartment OA } \\
(\text { age } 68.3 \pm 8.7)\end{array}$ & Ascent/ descent 5 steps & - & - & 1.80 \\
\hline
\end{tabular}


Table 4. (cont)

Stair times (in seconds) for musculoskeletal conditions (mean per step of baseline values for each group).

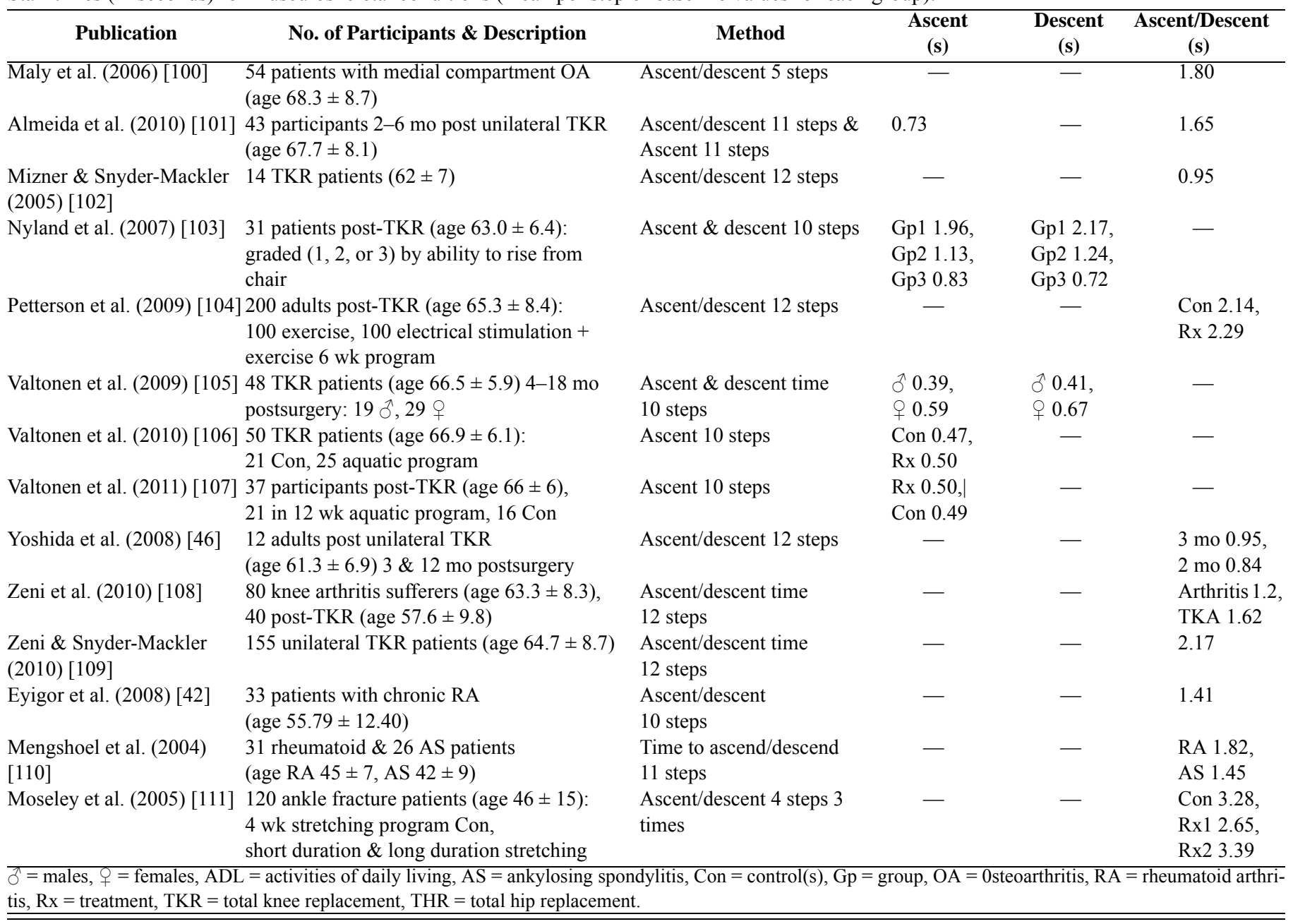

Table 5.

Summary of group data: (number of studies and number of participants contributing to result in parentheses), mean time (in seconds) \pm standard deviation to complete stair (ascent, descent, or ascent and descent together).

\begin{tabular}{llll}
\hline \multicolumn{1}{c}{ Group } & \multicolumn{1}{c}{ Ascent } & \multicolumn{1}{c}{ Descent } & \multicolumn{1}{c}{ Ascent/Descent } \\
\hline $18-49 \mathrm{yr}$ & $(10,2,089) 0.48 \pm 0.14$ & $(3,183) 0.50 \pm 0.14$ & No data \\
$50-65 \mathrm{yr}$ & $(2,54) 0.46+ \pm 0.17$ & $(2,54) 0.54 \pm 0.29$ & $(4,115) 0.90 \pm 0.27$ \\
$>65 \mathrm{yr}$ & $(10,1,049) 0.65 \pm 0.41$ & $(2,718) 1.4 \pm 0.55$ & $(9,1,598) 1.38 \pm 0.48$ \\
$>65 \mathrm{yr}$ with Decreased Mobility & $(5,254) 0.95 \pm 0.44$ & $(3,217) 1.11 \pm 0.47$ & $(1,45) 0.63$ \\
Neurological & $(9,315) 1.01 \pm 0.57$ & $(8,273) 0.9 \pm 0.47$ & $(2,54) 2.41 \pm 1.05$ \\
Medical & $(10,425) 0.6 \pm 0.15$ & $(3,81) 0.81 \pm 0.15$ & No data \\
Musculoskeletal & $(11,572) 0.82 \pm 0.33$ & $(6,376) 0.96 \pm 0.41$ & $(28,2,489) 1.77 \pm 0.60$ \\
\hline \hline
\end{tabular}

elderly and elderly with mobility limitations and a lack of data in the young healthy group make it difficult to elaborate further. Until further data are obtained for stair descent and combined ascent/descent, methodologies for stair testing should include both stair ascent and descent.
This methodology of testing provides the most challenging aspect of timed stair tests to be included, whether strength, balance, or joint range of motion is the major limiting factor. As a functional test with ceiling effects likely to be present for young healthy participants, 
instructions should include to do the test as fast as possible without the use of the handrail or aids.

More controllable and possibly important is the length of the stairway used for testing. The majority of studies use a stairway of 10 to 12 stairs for testing, which is likely to be the average flight length available in buildings and therefore a practical length for testing. The exception to this are those studies looking at medical conditions involving the heart and lungs, where longer stairways are used to elicit a more cardiovascular response. Combined stair ascent/descent is not considered in these studies because this would slow the participants down, decreasing the cardiovascular response. However, the influence of asking participants to complete the stairs as fast as possible may elicit a cardiovascular limitation in some populations and requires at least some consideration, if not investigation. Given the data to date, the inclusion of both stair ascent and descent is warranted and would include the greatest number of possible limitations.

Finally, as far as setting standardized testing procedures, the stair height should be considered. Building codes in Australia have a set range of acceptance for the steepness of stair flights, giving an element of consistency to the stair dimensions. However, the relative stair height to the participant is not compensated for in this manner. If the timed stair test is being used as a purely functional measure, it may be sufficient for the range of normal values, hopefully obtained more accurately and consistently in the future, to compensate for this. However, if strength or joint range is of interest, times are not as relevant and measures will need to be normalized for participant height. Therefore, timed stairs fall into the category of a more advanced functional measure and differentiating test over a wider age range in contrast to other commonly used functional tests, such as the timed up-and-go [14] and the 6 min walk test.

The major limitation of this review was our ability to extract all articles that use timed stair tests. Our search strategy was kept simple to obtain as many relevant articles as possible; however, many studies do not list all test methods in the abstract because they may be included to satisfy secondary objectives. In saying this, we still found it necessary to limit the data extraction further by adding the requirement of the stair methodology being as fast or quick as possible to enable articles to be compared with one another. This further information is not easily obtained through a search strategy and therefore complicates this type of review where a testing method is trying to be evaluated.

\section{CONCLUSIONS}

The recommendation from this review is that normative values for stair ascent and descent would be a useful clinical tool. There are still groups that have insufficient data from which to draw definite conclusions; however, the data obtained suggests that stair times change with age and can be used to differentiate between patient groups. We would recommend that further data are required for descent in the over $65 \mathrm{yr}$ olds and the young healthy, as well as combined ascent/descent in the young healthy, over 65 with mobility limitations, and neurological group because of low participant numbers and increasing SDs. Further information on the number of stairs to elicit a cardiovascular response would also be useful to see whether the command to complete the stairs as fast as possible may be sufficient to differentiate between people on a smaller flight of stairs.

Standardization of stair protocols for musculoskeletal and neurological problems would involve a flight of at least 10 stairs and would include both stair ascent and descent. Participants would be asked to complete the stairs as quickly as possible with the handrail only to be used for balance and no aids used.

\section{Key Points}

- Findings: The findings of this review are that a standardized methodology should be used for timed stair tests, with stair descent included either singularly or in combination with stair ascent.

- Implications: Presently there are not enough data for normative values across age ranges or patient groups; however, with a consistent methodology being used, there is evidence that this is an achievable goal with valuable information being available for both research and clinical purposes.

\section{ACKNOWLEDGMENTS}

\section{Author Contributions:}

Study concept and design: E. J. Nightingale, C. E. Hiller. Acquisition of data: E. J. Nightingale, C. E. Hiller, F. Pourkazemi. Analysis and interpretation of data: E. J. Nightingale, C. E. Hiller, F. Pourkazemi. 
Drafting of manuscript: E. J. Nightingale, C. E. Hiller, F. Pourkazemi. Financial Disclosures: The authors have declared that no competing interests exist.

Funding/Support: This material was unfunded at the time of manuscript preparation.

\section{REFERENCES}

1. Adegoke BO, Babatunde FO, Oyeyemi AL. Pain, balance, self-reported function and physical function in individuals with knee osteoarthritis. Physiother Theory Pract. 2012; 28(1):32-40. [PMID:21801103] http://dx.doi.org/10.3109/09593985.2011.570858

2. Bean JF, Kiely DK, LaRose S, Alian J, Frontera WR. Is stair climb power a clinically relevant measure of leg power impairments in at-risk older adults? Arch Phys Med Rehabil. 2007;88(5):604-9. [PMID:17466729] http://dx.doi.org/10.1016/j.apmr.2007.02.004

3. Cowley PM, Ploutz-Snyder LL, Baynard T, Heffernan K, Jae SY, Hsu S, Lee M, Pitetti KH, Reiman MP, Fernhall B. Physical fitness predicts functional tasks in individuals with Down syndrome. Med Sci Sports Exerc. 2010;42(2): 388-93. [PMID:19927019] http://dx.doi.org/10.1249/MSS.0b013e3181b07e7a

4. Ouellette MM, LeBrasseur NK, Bean JF, Phillips E, Stein J, Frontera WR, Fielding RA. High-intensity resistance training improves muscle strength, self-reported function, and disability in long-term stroke survivors. Stroke. 2004; 35(6):1404-9. [PMID:15105515] http://dx.doi.org/10.1161/01.STR.0000127785.73065.34

5. Storer TW, Casaburi R, Sawelson S, Kopple JD. Endurance exercise training during haemodialysis improves strength, power, fatigability and physical performance in maintenance haemodialysis patients. Nephrol Dial Transplant. 2005;20(7):1429-37. [PMID:15840667] http://dx.doi.org/10.1093/ndt/gfh784

6. van Iersel MB, Olde Rikkert MG, Mulley GP. Is stair negotiation measured appropriately in functional assessment scales? Clin Rehabil. 2003;17(3):325-33. [PMID:12735541] http://dx.doi.org/10.1191/0269215502cr628oa

7. Insall JN, Dorr LD, Scott RD, Scott WN. Rationale of the Knee Society clinical rating system. Clin Orthop Relat Res. 1989;(248):13-14. [PMID:2805470]

8. Herman T, Inbar-Borovsky N, Brozgol M, Giladi N, Hausdorff JM. The Dynamic Gait Index in healthy older adults: The role of stair climbing, fear of falling and gender. Gait Posture. 2009;29(2):237-41. [PMID:18845439] http://dx.doi.org/10.1016/j.gaitpost.2008.08.013

9. Rantanen T, Era P, Heikkinen E. Maximal isometric strength and mobility among 75-year-old men and women. Age Age- ing. 1994;23(2):132-37. [PMID:8023721]

http://dx.doi.org/10.1093/ageing/23.2.132

10. Riener R, Rabuffetti M, Frigo C. Stair ascent and descent at different inclinations. Gait Posture. 2002;15(1): 32-44. [PMID:11809579] http://dx.doi.org/10.1016/S0966-6362(01)00162-X

11. Andriacchi TP, Andersson GB, Fermier RW, Stern D, Galante JO. A study of lower-limb mechanics during stairclimbing. J Bone Joint Surg Am. 1980;62(5):749-57. [PMID:7391098]

12. McFadyen BJ, Winter DA. An integrated biomechanical analysis of normal stair ascent and descent. J Biomech. 1988;21(9):733-44. [PMID:3182877] http://dx.doi.org/10.1016/0021-9290(88)90282-5

13. Shiomi T. Effects of different patterns of stairclimbing on physiological cost and motor efficiency. J Hum Ergol (Tokyo). 1994;23(2):111-20. [PMID:7730596]

14. Butler AA, Menant JC, Tiedemann AC, Lord SR. Age and gender differences in seven tests of functional mobility. J Neuroeng Rehabil. 2009;6:31. [PMID:19642991] http://dx.doi.org/10.1186/1743-0003-6-31

15. Zaino CA, Marchese VG, Westcott SL. Timed up and down stairs test: Preliminary reliability and validity of a new measure of functional mobility. Pediatr Phys Ther. 2004;16(2):90-98. [PMID:17057533] http://dx.doi.org/10.1097/01.PEP.0000127564.08922.6A

16. Alzahrani MA, Dean CM, Ada L. Ability to negotiate stairs predicts free-living physical activity in communitydwelling people with stroke: An observational study. Aust J Physiother. 2009;55(4):277-81. [PMID:19929771] http://dx.doi.org/10.1016/S0004-9514(09)70008-X

17. Lepage C, Noreau L, Bernard PM. Association between characteristics of locomotion and accomplishment of life habits in children with cerebral palsy. Phys Ther. 1998; 78(5):458-69. [PMID:9597060]

18. Tiedemann AC, Sherrington C, Lord SR. Physical and psychological factors associated with stair negotiation performance in older people. J Gerontol A Biol Sci Med Sci. 2007;62(11):1259-65. [PMID:18000146] http://dx.doi.org/10.1093/gerona/62.11.1259

19. Bohannon RW. Reference values for the timed up and go test: A descriptive meta-analysis. J Geriatr Phys Ther. 2006;29(2):64-68. [PMID:16914068] http://dx.doi.org/10.1519/00139143-200608000-00004

20. Verbeek J, Ruotsalainen J, Hoving JL. Synthesizing study results in a systematic review. Scand J Work Environ Health. 2012;38(3):282-90. [PMID:22015561] http://dx.doi.org/10.5271/sjweh.3201

21. Schiller BC, Casas YG, Tracy BL, DeSouza CA, Seals DR. Age-related declines in knee extensor strength and physical performance in healthy Hispanic and Caucasian women. J Gerontol A Biol Sci Med Sci. 2000;55(12): 
B563-69. [PMID:11129385]

http://dx.doi.org/10.1093/gerona/55.12.B563

22. Wilken JM, Darter BJ, Goffar SL, Ellwein JC, Snell RM, Tomalis EA, Shaffer SW. Physical performance assessment in military service members. J Am Acad Orthop Surg. 2012;20(Suppl 1):S42-47. [PMID:22865136] http://dx.doi.org/10.5435/JAAOS-20-08-S42

23. Hughes $\mathrm{C}$, Osman C, Woods AK. Relationship among performance on stair ambulation, functional reach, and timed up and go tests in older adults. Issues on Aging. 1998;21(3):18-22.

24. Mizner RL, Petterson SC, Clements KE, Zeni JA Jr, Irrgang JJ, Snyder-Mackler L. Measuring functional improvement after total knee arthroplasty requires both performance-based and patient-report assessments: A longitudinal analysis of outcomes. J Arthroplasty. 2011; 26(5):728-37. [PMID:20851566] http://dx.doi.org/10.1016/j.arth.2010.06.004

25. Teh KC, Aziz AR. A stair-climb test of cardiorespiratory fitness for Singapore. Singapore Med J. 2000;41(12): 588-94. [PMID:11296784]

26. Teh KC, Aziz AR. Heart rate, oxygen uptake, and energy cost of ascending and descending the stairs. Med Sci Sports Exerc. 2002;34(4):695-99. [PMID:11932581] http://dx.doi.org/10.1097/00005768-200204000-00021

27. Lindeman E, Leffers P, Reulen J, Spaans F, Drukker J. Quadriceps strength and timed motor performances in myotonic dystrophy, Charcot-Marie-Tooth disease, and healthy subjects. Clin Rehabil. 1998;12(2):127-35.

[PMID:9619654]

http://dx.doi.org/10.1191/026921598667776775

28. Bonnyaud C, Zory R, Pradon D, Vuillerme N, Roche N. Clinical and biomechanical factors which predict timed up and down stairs test performance in hemiparetic patients. Gait Posture. 2013;38(3):466-70.

[PMID:23433546]

http://dx.doi.org/10.1016/j.gaitpost.2013.01.015

29. Alzahrani M, Dean C, Ada L. Relationship between walking performance and types of community-based activities in people with stroke: An observational study. Rev Bras Fisioter. 2011;15(1):45-51. [PMID:21390472]

30. Lin YC, Davey RC, Cochrane T. Tests for physical function of the elderly with knee and hip osteoarthritis. Scand J Med Sci Sports. 2001;11(5):280-86. [PMID:11696212] http://dx.doi.org/10.1034/j.1600-0838.2001.110505.x

31. Lord SR, Murray SM, Chapman K, Munro B, Tiedemann A. Sit-to-stand performance depends on sensation, speed, balance, and psychological status in addition to strength in older people. J Gerontol A Biol Sci Med Sci. 2002; 57(8):M539-43. [PMID:12145369] http://dx.doi.org/10.1093/gerona/57.8.M539
32. Ng SS, Hui-Chan CW. The timed up \& go test: Its reliability and association with lower-limb impairments and locomotor capacities in people with chronic stroke. Arch Phys Med Rehabil. 2005;86(8):1641-47. [PMID:16084820] http://dx.doi.org/10.1016/j.apmr.2005.01.011

33. Podsiadlo D, Richardson S. The timed "Up \& Go": A test of basic functional mobility for frail elderly persons. J Am Geriatr Soc. 1991;39(2):142-48. [PMID:1991946]

34. Brandon LJ, Gaasch DA, Boyette LW, Lloyd AM. Effects of long-term resistive training on mobility and strength in older adults with diabetes. J Gerontol A Biol Sci Med Sci. 2003;58(8):740-45. [PMID:12902533] http://dx.doi.org/10.1093/gerona/58.8.M740

35. Cowley PM, Ploutz-Snyder LL, Baynard T, Heffernan KS, Jae SY, Hsu S, Lee M, Pitetti KH, Reiman MP, Fernhall $\mathrm{B}$. The effect of progressive resistance training on leg strength, aerobic capacity and functional tasks of daily living in persons with Down syndrome. Disabil Rehabil. 2011;33(23-24):2229-36. [PMID:21446859] http://dx.doi.org/10.3109/09638288.2011.563820

36. Haus JM, Carrithers JA, Trappe SW, Trappe TA. Collagen, cross-linking, and advanced glycation end products in aging human skeletal muscle. J Appl Physiol. 2007; 103(6):2068-76. [PMID:17901242] http://dx.doi.org/10.1152/japplphysiol.00670.2007

37. LeBrasseur NK, Bhasin S, Miciek R, Storer TW. Tests of muscle strength and physical function: Reliability and discrimination of performance in younger and older men and older men with mobility limitations. J Am Geriatr Soc. 2008;56(11):2118-23. [PMID:18811607] http://dx.doi.org/10.1111/j.1532-5415.2008.01953.x

38. Sartorio A, Fontana P, Trecate L, Lafortuna CL. Shortterm changes of fatigability and muscle performance in severe obese patients after an integrated body mass reduction program. Diabetes Nutr Metab. 2003;16(2):88-93. [PMID:12846447]

39. Sartorio A, Lafortuna CL, Agosti F, Proietti M, Maffiuletti NA. Elderly obese women display the greatest improvement in stair climbing performance after a 3week body mass reduction program. Int $\mathrm{J}$ Obes Relat Metab Disord. 2004;28(9):1097-1104. [PMID:15211371] http://dx.doi.org/10.1038/sj.ijo.0802702

40. Sartorio A, Lafortuna CL, Conte G, Faglia G, Narici MV. Changes in motor control and muscle performance after a short-term body mass reduction program in obese subjects. J Endocrinol Invest. 2001;24(6):393-98. [PMID:11434662]

41. Sartorio A, Narici MV, Fumagalli E, Faglia G, Lafortuna $\mathrm{CL}$. Aerobic and anaerobic performance before and after a short-term body mass reduction program in obese subjects. Diabetes Nutr Metab. 2001;14(1):51-57. [PMID:11345166] 
42. Eyigor S, Kirazli Y, Capaci K, Oder G, Tarhan F, Inal V. Isokinetic ankle plantarflexion and dorsiflexion strength in patients with rheumatoid arthritis. Isokinet Exerc Sci. 2008;16(1):25-31.

43. Grant S, Todd K, Aitchison TC, Kelly P, Stoddart D. The effects of a 12-week group exercise programme on physiological and psychological variables and function in overweight women. Public Health. 2004;118(1):31-42.

[PMID:14643625]

http://dx.doi.org/10.1016/S0033-3506(03)00131-8

44. Parisi SL, Héroux ME, Culham EG, Norman KE. Functional mobility and postural control in essential tremor. Arch Phys Med Rehabil. 2006;87(10):1357-64.

[PMID:17023246]

http://dx.doi.org/10.1016/j.apmr.2006.07.255

45. Petterson SC, Raisis L, Bodenstab A, Snyder-Mackler L. Disease-specific gender differences among total knee arthroplasty candidates. J Bone Joint Surg Am. 2007; 89(11):2327-33. [PMID:17974873]

http://dx.doi.org/10.2106/JBJS.F.01144

46. Yoshida Y, Mizner RL, Ramsey DK, Snyder-Mackler L. Examining outcomes from total knee arthroplasty and the relationship between quadriceps strength and knee function over time. Clin Biomech (Bristol, Avon). 2008;23(3): 320-28. [PMID:18060669] http://dx.doi.org/10.1016/j.clinbiomech.2007.10.008

47. Capodaglio P, Capodaglio Edda M, Facioli M, Saibene F. Long-term strength training for community-dwelling people over 75: Impact on muscle function, functional ability and life style. Eur J Appl Physiol. 2007;100(5):535-42. [PMID:16636856] http://dx.doi.org/10.1007/s00421-006-0195-8

48. Christiansen CL, Stevens-Lapsley JE. Weight-bearing asymmetry in relation to measures of impairment and functional mobility for people with knee osteoarthritis. Arch Phys Med Rehabil. 2010;91(10):1524-28. [PMID:20875509] http://dx.doi.org/10.1016/j.apmr.2010.07.009

49. Eyigor S, Karapolat H, Durmaz B. Effects of a groupbased exercise program on the physical performance, muscle strength and quality of life in older women. Arch Gerontol Geriatr. 2007;45(3):259-71. [PMID:17303264] http://dx.doi.org/10.1016/j.archger.2006.12.001

50. Eyigor S, Karapolat H, Durmaz B, Ibisoglu U, Cakir S. A randomized controlled trial of Turkish folklore dance on the physical performance, balance, depression and quality of life in older women. Arch Gerontol Geriatr. 2009; 48(1):84-88. [PMID:18068829] http://dx.doi.org/10.1016/j.archger.2007.10.008

51. Farquhar S, Snyder-Mackler L. The Chitranjan Ranawat Award: The nonoperated knee predicts function 3 years after unilateral total knee arthroplasty. Clin Orthop Relat
Res. 2010;468(1):37-44. [PMID:19472024]

http://dx.doi.org/10.1007/s11999-009-0892-9

52. Galvão DA, Taaffe DR. Resistance exercise dosage in older adults: single- versus multiset effects on physical performance and body composition. J Am Geriatr Soc. 2005;53(12):2090-97. [PMID:16398892]

http://dx.doi.org/10.1111/j.1532-5415.2005.00494.x

53. Henwood TR, Taaffe DR. Short-term resistance training and the older adult: The effect of varied programmes for the enhancement of muscle strength and functional performance. Clin Physiol Funct Imaging. 2006;26(5):305-13. [PMID:16939509] http://dx.doi.org/10.1111/j.1475-097X.2006.00695.x

54. Hirota C, Watanabe M, Sun W, Tanimoto Y, Kono R, Takasaki K, Kono K. Association between the Trail Making Test and physical performance in elderly Japanese. Geriatr Gerontol Int. 2010;10(1):40-47. [PMID:20102381] http://dx.doi.org/10.1111/j.1447-0594.2009.00557.x

55. Miller GD, Rejeski WJ, Williamson JD, Morgan T, Sevick MA, Loeser RF, Ettinger WH, Messier SP; ADAPT Investigators. The Arthritis, Diet and Activity Promotion Trial (ADAPT): design, rationale, and baseline results. Control Clin Trials. 2003;24(4):462-80.

[PMID:12865040] http://dx.doi.org/10.1016/S0197-2456(03)00063-1

56. Morie M, Reid KF, Miciek R, Lajevardi N, Choong K, Krasnoff JB, Storer TW, Fielding RA, Bhasin S, Lebrasseur NK. Habitual physical activity levels are associated with performance in measures of physical function and mobility in older men. J Am Geriatr Soc. 2010;58(9): 1727-33. [PMID:20738436] http://dx.doi.org/10.1111/j.1532-5415.2010.03012.x

57. Rees S, Murphy A, Watsford M. Effects of vibration exercise on muscle performance and mobility in an older population. J Aging Phys Act. 2007;15(4):367-81. [PMID:18048942]

58. Sayers SP, Bean J, Cuoco A, LeBrasseur NK, Jette A, Fielding RA. Changes in function and disability after resistance training: does velocity matter?: a pilot study. Am J Phys Med Rehabil. 2003;82(8):605-13.

[PMID:12872017] http://dx.doi.org/10.1097/01.PHM.0000078225.71442.B6

59. Hiroyuki S, Uchiyama Y, Kakurai S. Specific effects of balance and gait exercises on physical function among the frail elderly. Clin Rehabil. 2003;17(5):472-79.

[PMID:12952151] http://dx.doi.org/10.1191/0269215503cr638oa

60. Sun W, Watanabe M, Hirota C, Tanimoto Y, Kono R, Takasaki K, Kono K. Obstacle-negotiating gait and related physical measurement indicators for the community-dwelling elderly in Japan. Arch Gerontol Geriatr. 
2010;50(3):e41-45. [PMID:19596458]

http://dx.doi.org/10.1016/j.archger.2009.01.016

61. Suzuki T, Bean JF, Fielding RA. Muscle power of the ankle flexors predicts functional performance in community-dwelling older women. J Am Geriatr Soc. 2001; 49(9):1161-67. [PMID:11559374]

http://dx.doi.org/10.1046/j.1532-5415.2001.49232.x

62. Vincent KR, Braith RW, Feldman RA, Magyari PM, Cutler RB, Persin SA, Lennon SL, Gabr AH, Lowenthal DT. Resistance exercise and physical performance in adults aged 60 to 83. J Am Geriatr Soc. 2002;50(6):1100-1107. [PMID:12110072] http://dx.doi.org/10.1046/j.1532-5415.2002.50267.x

63. Bean J, Herman S, Kiely DK, Callahan D, Mizer K, Frontera WR, Fielding RA. Weighted stair climbing in mobility-limited older people: A pilot study. J Am Geriatr Soc. 2002;50(4):663-70. [PMID:11982666] http://dx.doi.org/10.1046/j.1532-5415.2002.50160.x

64. Fahlman M, Morgan AL, McNevin N, Topp R, Boardley DJ. Combination training and resistance training as effective interventions to improve functioning in elders. J Aging Phys Act. 2007;15(2):195-205.

65. Fahlman MM, Topp R, McNevin N, Morgan AL, Boardley DJ. Structured exercise in older adults with limited functional ability. J Gerontol Nurs. 2007;33(6):32-39. [PMID:17598625]

66. Herman S, Kiely DK, Leveille S, O’Neill E, Cyberey S, Bean JF. Upper and lower limb muscle power relationships in mobility-limited older adults. J Gerontol A Biol Sci Med Sci. 2005;60(4):476-80. [PMID:15933387] http://dx.doi.org/10.1093/gerona/60.4.476

67. Erel S, Uygur F, Engin Simsek I, Yakut Y. The effects of dynamic ankle-foot orthoses in chronic stroke patients at three-month follow-up: A randomized controlled trial. Clin Rehabil. 2011;25(6):515-23. [PMID:21285288] http://dx.doi.org/10.1177/0269215510390719

68. Flansbjer U-B, Downham D, Lexell J. Knee muscle strength, gait performance, and perceived participation after stroke. Arch Phys Med Rehabil. 2006;87(7):974-80. [PMID:16813786] http://dx.doi.org/10.1016/j.apmr.2006.03.008

69. Dibble LE, Hale TF, Marcus RL, Droge J, Gerber JP, LaStayo PC. High-intensity resistance training amplifies muscle hypertrophy and functional gains in persons with Parkinson's disease. Mov Disord. 2006;21(9):1444-52. [PMID:16773643] http://dx.doi.org/10.1002/mds.20997

70. Hayes HA, Gappmaier E, LaStayo PC. Effects of highintensity resistance training on strength, mobility, balance, and fatigue in individuals with multiple sclerosis: A randomized controlled trial. J Neurol Phys Ther. 2011;35(1):
2-10. [PMID:21475078]

http://dx.doi.org/10.1097/NPT.0b013e31820b5a9d

71. Lindeman E, Leffers P, Reulen J, Spaans F, Drukker J. Reduction of knee torques and leg-related functional abilities in hereditary motor and sensory neuropathy. Arch Phys Med Rehabil. 1994;75(11):1201-5. [PMID:7979929] http://dx.doi.org/10.1016/0003-9993(94)90005-1

72. Gammage M, Schofield S, Rankin I, Bennett M, Coles P, Pentecost B. Benefit of single setting rate responsive ventricular pacing compared with fixed rate demand pacing in elderly patients. Pacing Clin Electrophysiol. 1991;14(2 Pt 1):174-80. [PMID:1706502] http://dx.doi.org/10.1111/j.1540-8159.1991.tb05087.x

73. Cataneo DC, Kobayasi S, Carvalho LR, Paccanaro RC, Cataneo AJ. Accuracy of six minute walk test, stair test and spirometry using maximal oxygen uptake as gold standard. Acta Cir Bras. 2010;25(2):194-200.

[PMID:20305888]

http://dx.doi.org/10.1590/S0102-86502010000200013

74. Pancieri MV, Cataneo DC, Montovani JC, Cataneo AJ. Comparison between actual and predicted postoperative stair-climbing test, walk test and spirometric values in patients undergoing lung resection. Acta Cir Bras. 2010; 25(6):535-40. [PMID:21120287] http://dx.doi.org/10.1590/S0102-86502010000600014

75. Kongsgaard M, Backer V, Jørgensen K, Kjaer M, Beyer N. Heavy resistance training increases muscle size, strength and physical function in elderly male COPD-patients-a pilot study. Respir Med. 2004;98(10):1000-1007.

[PMID:15481277] http://dx.doi.org/10.1016/j.rmed.2004.03.003

76. Rejeski WJ, Foley KO, Woodard CM, Zaccaro DJ, Berry MJ. Evaluating and understanding performance testing in COPD patients. J Cardiopulm Rehabil. 2000;20(2):79-88. [PMID:10763155] http://dx.doi.org/10.1097/00008483-200003000-00001

77. Galvão DA, Nosaka K, Taaffe DR, Spry N, Kristjanson LJ, McGuigan MR, Suzuki K, Yamaya K, Newton RU. Resistance training and reduction of treatment side effects in prostate cancer patients. Med Sci Sports Exerc. 2006; 38(12):2045-52. [PMID:17146309] http://dx.doi.org/10.1249/01.mss.0000233803.48691.8b

78. LaStayo PC, Marcus RL, Dibble LE, Smith SB, Beck SL. Eccentric exercise versus usual-care with older cancer survivors: The impact on muscle and mobility-an exploratory pilot study. BMC Geriatr. 2011;11:5.

[PMID:21272338] http://dx.doi.org/10.1186/1471-2318-11-5

79. Mercer TH, Crawford C, Gleeson NP, Naish PF. Lowvolume exercise rehabilitation improves functional capacity and self-reported functional status of dialysis patients. Am J 
Phys Med Rehabil. 2002;81(3):162-67. [PMID:11989511] http://dx.doi.org/10.1097/00002060-200203000-00002

80. Mercer TH, Naish PF, Gleeson NP, Wilcock JE, Crawford C. Development of a walking test for the assessment of functional capacity in non-anaemic maintenance dialysis patients. Nephrol Dial Transplant. 1998;13(8):2023-26. [PMID:9719158] http://dx.doi.org/10.1093/ndt/13.8.2023

81. Galea MP, Levinger P, Lythgo N, Cimoli C, Weller R, Tully E, McMeeken J, Westh R. A targeted home- and center-based exercise program for people after total hip replacement: A randomized clinical trial. Arch Phys Med Rehabil. 2008;89(8):1442-47. [PMID:18586222] http://dx.doi.org/10.1016/j.apmr.2007.11.058

82. Pua YH, Clark RA, Bryant AL. Physical function in hip osteoarthritis: Relationship to isometric knee extensor steadiness. Arch Phys Med Rehabil. 2010;91(7):1110-16. [PMID:20599051] http://dx.doi.org/10.1016/j.apmr.2010.04.001

83. Pua YH, Cowan SM, Wrigley TV, Bennell KL. The Lower Extremity Functional Scale could be an alternative to the Western Ontario and McMaster Universities Osteoarthritis Index physical function scale. J Clin Epidemiol. 2009;62(10):1103-11. [PMID:19282145] http://dx.doi.org/10.1016/j.jclinepi.2008.11.011

84. Marsh AP, Rejeski WJ, Lang W, Miller ME, Messier SP. Baseline balance and functional decline in older adults with knee pain: The Observational Arthritis Study in Seniors. J Am Geriatr Soc. 2003;51(3):331-39. [PMID:12588576] http://dx.doi.org/10.1046/j.1532-5415.2003.51106.x

85. Miller GD, Nicklas BJ, Davis C, Loeser RF, Lenchik L, Messier SP. Intensive weight loss program improves physical function in older obese adults with knee osteoarthritis. Obesity (Silver Spring). 2006;14(7):1219-30. [PMID:16899803] http://dx.doi.org/10.1038/oby.2006.139

86. Miller GD, Nicklas BJ, Loeser RF. Inflammatory biomarkers and physical function in older, obese adults with knee pain and self-reported osteoarthritis after intensive weightloss therapy. J Am Geriatr Soc. 2008;56(4):644-51. [PMID:18312558] http://dx.doi.org/10.1111/j.1532-5415.2007.01636.x

87. Durmuş D, Alayli G, Cantürk F. Effects of quadriceps electrical stimulation program on clinical parameters in the patients with knee osteoarthritis. Clin Rheumatol. 2007;26(5):674-78. [PMID:16897119] http://dx.doi.org/10.1007/s10067-006-0358-3

88. Mizner RL, Petterson SC, Snyder-Mackler L. Quadriceps strength and the time course of functional recovery after total knee arthroplasty. J Orthop Sports Phys Ther. 2005; 35(7):424-36. [PMID:16108583] http://dx.doi.org/10.2519/jospt.2005.35.7.424
89. Mizner RL, Petterson SC, Stevens JE, Axe MJ, SnyderMackler L. Preoperative quadriceps strength predicts functional ability one year after total knee arthroplasty. J Rheumatol. 2005;32(8):1533-39. [PMID:16078331]

90. Ni G-X, Song L, Yu B, Huang C-H, Lin J-H. Tai chi improves physical function in older Chinese women with knee osteoarthritis [Retraction in Schumacher HR. J Clin Rheumatol. 2010;16(7):357; PMID: 20921858]. J Clin Rheumatol. 2010;16(2):64-67. [PMID:20130482] http://dx.doi.org/10.1097/RHU.0b013e3181cf344f

91. Rejeski WJ, Ettinger WH Jr, Schumaker S, James P, Burns R, Elam JT. Assessing performance-related disability in patients with knee osteoarthritis. Osteoarthritis Cartilage. 1995;3(3):157-67. [PMID:8581745] http://dx.doi.org/10.1016/S1063-4584(05)80050-0

92. Swank AM, Kachelman JB, Bibeau W, Quesada PM, Nyland J, Malkani A, Topp RV. Prehabilitation before total knee arthroplasty increases strength and function in older adults with severe osteoarthritis. J Strength Cond Res. 2011;25(2):318-25. [PMID:21217530] http://dx.doi.org/10.1519/JSC.0b013e318202e431

93. Talbot LA, Gaines JM, Huynh TN, Metter EJ. A homebased pedometer-driven walking program to increase physical activity in older adults with osteoarthritis of the knee: A preliminary study. J Am Geriatr Soc. 2003;51(3): 387-92. [PMID:12588583] http://dx.doi.org/10.1046/j.1532-5415.2003.51113.x

94. Talbot LA, Gaines JM, Ling SM, Metter EJ. A homebased protocol of electrical muscle stimulation for quadriceps muscle strength in older adults with osteoarthritis of the knee. J Rheumatol. 2003;30(7):1571-78. [PMID:12858461]

95. Topp R, Woolley S, Hornyak J 3rd, Khuder S, Kahaleh B. The effect of dynamic versus isometric resistance training on pain and functioning among adults with osteoarthritis of the knee. Arch Phys Med Rehabil. 2002;83(9):1187-95. [PMID:12235596] http://dx.doi.org/10.1053/apmr.2002.33988

96. Gür H, Cakin N. Muscle mass, isokinetic torque, and functional capacity in women with osteoarthritis of the knee. Arch Phys Med Rehabil. 2003;84(10):1534-41. [PMID:14586923] http://dx.doi.org/10.1016/S0003-9993(03)00288-0

97. Jan MH, Tang PF, Lin JJ, Tseng SC, Lin YF, Lin DH. Efficacy of a target-matching foot-stepping exercise on proprioception and function in patients with knee osteoarthritis. J Orthop Sports Phys Ther. 2008;38(1):19-25. [PMID:18357655] http://dx.doi.org/10.2519/jospt.2008.2512

98. Kraemer WJ, Ratamess NA, Anderson JM, Maresh CM, Tiberio DP, Joyce ME, Messinger BN, French DN, Rubin MR, Gómez AL, Volek JS, Hesslink R Jr. Effect of a cetylated fatty acid topical cream on functional mobility and 
quality of life of patients with osteoarthritis. J Rheumatol. 2004;31(4):767-74. [PMID:15088305]

99. Maly MR, Costigan PA, Olney SJ. Contribution of psychosocial and mechanical variables to physical performance measures in knee osteoarthritis. Phys Ther. 2005; 85(12):1318-28. [PMID:163052701]

100. Maly MR, Costigan PA, Olney SJ. Determinants of selfreport outcome measures in people with knee osteoarthritis. Arch Phys Med Rehabil. 2006;87(1):96-104.

[PMID:16401446]

http://dx.doi.org/10.1016/j.apmr.2005.08.110

101. Almeida GJ, Schroeder CA, Gil AB, Fitzgerald GK, Piva SR. Interrater reliability and validity of the stair ascend/ descend test in subjects with total knee arthroplasty. Arch Phys Med Rehabil. 2010;91(6):932-38.

[PMID:20510986]

http://dx.doi.org/10.1016/j.apmr.2010.02.003

102. Mizner RL, Snyder-Mackler L. Altered loading during walking and sit-to-stand is affected by quadriceps weakness after total knee arthroplasty. J Orthop Res. 2005; 23(5):1083-90. [PMID:16140191] http://dx.doi.org/10.1016/j.orthres.2005.01.021

103. Nyland J, Frost K, Quesada P, Angeli C, Swank A, Topp R, Malkani AL. Self-reported chair-rise ability relates to stair-climbing readiness of total knee arthroplasty patients: A pilot study. J Rehabil Res Dev. 2007;44(5): 751-59. [PMID:17943686] http://dx.doi.org/10.1682/JRRD.2006.11.0146

104. Petterson SC, Mizner RL, Stevens JE, Raisis L, Bodenstab A, Newcomb W, Snyder-Mackler L. Improved function from progressive strengthening interventions after total knee arthroplasty: A randomized clinical trial with an imbedded prospective cohort. Arthritis Rheum. 2009; 61(2):174-83. [PMID:19177542] http://dx.doi.org/10.1002/art.24167

105. Valtonen A, Pöyhönen T, Heinonen A, Sipilä S. Muscle deficits persist after unilateral knee replacement and have implications for rehabilitation. Phys Ther. 2009;89(10): 1072-79. [PMID:19713269] http://dx.doi.org/10.2522/ptj.20070295

106. Valtonen A, Pöyhönen T, Sipilä S, Heinonen A. Effects of aquatic resistance training on mobility limitation and lower-limb impairments after knee replacement. Arch Phys Med Rehabil. 2010;91(6):833-39. [PMID:20510971] http://dx.doi.org/10.1016/j.apmr.2010.03.002

107. Valtonen A, Pöyhönen T, Sipilä S, Heinonen A. Maintenance of aquatic training-induced benefits on mobility and lower-extremity muscles among persons with unilateral knee replacement. Arch Phys Med Rehabil. 2011; 92(12):1944-50. [PMID:22133241] http://dx.doi.org/10.1016/j.apmr.2011.07.191

108. Zeni JA Jr, Axe MJ, Snyder-Mackler L. Clinical predictors of elective total joint replacement in persons with end-stage knee osteoarthritis. BMC Musculoskelet Disord. 2010;11:86. [PMID:20459622] http://dx.doi.org/10.1186/1471-2474-11-86

109. Zeni JA Jr, Snyder-Mackler L. Early postoperative measures predict 1- and 2-year outcomes after unilateral total knee arthroplasty: Importance of contralateral limb strength. Phys Ther. 2010;90(1):43-54. [PMID:19959653] http://dx.doi.org/10.2522/ptj.20090089

110. Mengshoel AM, Jokstad K, Bjerkhoel F. Associations between walking time, quadriceps muscle strength and cardiovascular capacity in patients with rheumatoid arthritis and ankylosing spondylitis. Clin Rheumatol. 2004;23(4):299-305. [PMID:15293089] http://dx.doi.org/10.1007/s10067-004-0896-5

111. Moseley AM, Herbert RD, Nightingale EJ, Taylor DA, Evans TM, Robertson GJ, Gupta SK, Penn J. Passive stretching does not enhance outcomes in patients with plantarflexion contracture after cast immobilization for ankle fracture: A randomized controlled trial. Arch Phys Med Rehabil. 2005;86(6):1118-26. [PMID:15954049] http://dx.doi.org/10.1016/j.apmr.2004.11.017

Submitted for publication June 23, 2013. Accepted in revised form October 2, 2013.

This article and any supplementary material should be cited as follows:

Nightingale EJ, Pourkazemi F, Hiller CE. Systematic review of timed stair tests. J Rehabil Res Dev. 2014; 51(3):335-50.

http://dx.doi.org/10.1682/JRRD.2013.06.0148

ResearcherID/ORCID: Elizabeth Jean Nightingale, PhD: E4586-2014; Fereshteh Pourkazemi, MSc(Physiotherapy): E-4489-2014

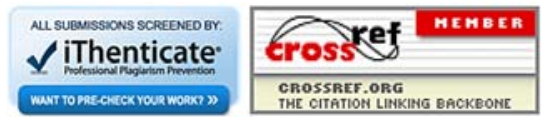

